\title{
Międzynarodowa konferencja naukowa pt. Kościól $i$ jego prawo w nauczaniu św. Jana Pawła II, Lublin, 9 czerwca 2017 r.
}

W trzydziestą rocznicę wizyty papieża Jana Pawła II na Katolickim Uniwersytecie Lubelskim została zorganizowana przez Katedrę Prawa Wyznaniowego KUL Międzynarodowa Konferencja Naukowa pt. Kościót i jego prawo w nauczaniu św. Jana Pawła II. Celem konferencji było podjęcie refleksji nad bogatą i różnorodną działalnością prawodawczą papieża Jana Pawła II oraz Jego koncepcją prawa Kościoła.

Obrady poprzedziła msza św. w kościele akademickim, której przewodniczył ks. dr hab. Andrzej Kiciński, prof. KUL - prorektor Katolickiego Uniwersytetu Lubelskiego Jana Pawła II. Podczas niej homilię wygłosił ks. prof. dr Libero Gerosa z Międzynarodowego Instytutu Prawa Kanonicznego i Prawa Porównawczego Religijnego w Lugano. Otwarcia konferencji w imieniu organizatorów dokonał ks. dr hab. Piotr Stanisz, prof. KUL kierownik Katedry Prawa Wyznaniowego. Na wstępie głos zabrali: dr hab. Krzysztof Wiak, prof. KUL - dziekan Wydziału Prawa, Prawa Kanonicznego i Administracji, który także odczytał list skierowany do uczestników konferencji przez Rektora KUL ks. prof. dra hab. Antoniego Dębińskiego, oraz dr hab. Przemysław Czarnek - Wojewoda Lubelski. Następnie przedstawiono prezentację przypominającą przebieg wizyty Jana Pawła II na KUL oraz najważniejsze fragmenty jego wystąpień podczas tego wydarzenia.

Obrady zostały podzielone na trzy sesje. Pierwszej części przewodniczył ks. bp dr hab. Artur Miziński - Sekretarz Generalny Konferencji Episkopatu Polski. Podczas jej trwania z referatami wystąpiło trzech prelegentów. Pierwszym z nich był ks. prof. dr Libero Gerosa, który zaprezentowat temat Interpretazione delle leggi canoniche e nuova evangelizzazione: la lezione innovativa di San Giovanni Paulo II (Interpretacja ustaw kanonicznych a nowa ewangelizacja: innowacyjna lekcja św. Jana Pawła II). Prelegent podkreślił wpływ duchowości św. Jana Pawła II na jego działalność prawodawczą i ewangelizacyjną. Zaprezentował także metodę interpretacji ustaw kościelnych opartą na Piśmie Świętym, Tradycji Kościoła oraz dokumentach Soboru Watykańskiego II. Kolejny referat - Jan Pawet II jako promotor świętości - wygłosił o. prof. dr hab. Wiesław Bar (KUL) wskazując na związek pomiędzy nową ewangelizacją a promowaniem świętości przez Jana Pawła II. Prelegent przybliżył zmiany 
wprowadzone przez Papieża Polaka w zakresie procedury beatyfikacyjnej i kanonizacyjnej oraz znaczenie tych aktów dla życia Kościoła, zwłaszcza w perspektywie tzw. ,waloru eklezjalnego sprawy”, którego istnienie jest jedną z podstawowych przesłanek procesu beatyfikacyjnego. Wystąpienie kończące pierwszą sesję wygłosił ks. dr hab. Leszek Adamowicz (KUL) mówiąc o kodyfikacjach Jana Pawła II. Prelegent zreferował pracę nad obowiązującymi obecnie kodeksami prawa kanonicznego (dla Kościoła łacińskiego i Katolickich Kościołów Wschodnich) zwracając uwagę na osobiste zaangażowanie Papieża Polaka w ich powstawanie.

Drugą sesję, której przewodniczył prof. ndzw. dr hab. Krzysztof Wiak, rozpoczął referat prof. dr Gaetano Dammacco z Uniwersytetu Aldo Moro w Bari pt. Il diritto degli emarginati nell'insegnamento di Giovanni Paolo II (Prawa osób wykluczonych w nauczaniu Jana Pawła II). W swoim wystąpieniu prof. Dammacco wskazał na związek jaki Papież Polak widział pomiędzy ubóstwem a wykluczeniem, które może nastąpić zarówno na poziomie indywidualnym jak i zbiorowym (np. wykluczenie narodów). Następnie prof. ndzw. dr hab. Alicja Grześkowiak z Kujawsko-Pomorskiej Szkoły Wyższej w Bydgoszczy zaprezentowała wystąpienie Ochrona życia w nauczaniu Jana Pawła II. Wg Prelegentki kwestia ochrony życia, zwłaszcza w jego początkowej i końcowej fazie była jedną z najważniejszych w całym nauczaniu Jana Pawła II. Prof. Grześkowiak zwróciła uwagę na wielokrotne apele Jana Pawła II o zagwarantowanie w prawodawstwach państwowych pełnej ochrony życia, a także na obowiązek katolickich polityków dokładania starań w zrealizowaniu tejże ochrony. Poza tym Jan Paweł II wskazywał na konieczność zapewnienia wsparcia rodzinie poprzez odpowiednią politykę społeczną i zdrowotną. Referat kończący drugą sesję pt. Jan Paweł II o roli Kościoła w Europie wygłosił ks. prof. dr hab. Piotr Mazurkiewicz z Uniwersytetu Kardynała Stefana Wyszyńskiego w Warszawie podkreślając m.in. znaczenie inkulturacji wiary. Prelegent odwołał się do adhortacji Jana Pawła II Ecclesia in Europa i wskazał na aktualność problemów, na które zwracał w niej uwagę Papież Polak, takich jak kryzys tożsamości europejskiej, problemy demograficzne, czy postępująca sekularyzacja. Zjawiska te, zgodnie z przywołanym dokumentem, determinują konieczność ponownej ewangelizacji w Europie. Ksiądz Profesor zwrócił uwagę na potrzebę zaangażowania katolików w sferę życia publicznego, w tym w proces prawodawczy.

Ostatniej sesji przewodniczył Wojewoda Lubelski i adiunkt Katedry Prawa Konstytucyjnego KUL dr hab. Przemysław Czarnek. Pierwszy 
referat $\mathrm{w}$ tej sesji - La libertà religiosa negli insegnamenti di Giovanni Paolo II (Wolność religijna w nauczaniu Jana Pawła II) - wygłosił prof. dr Giorgio Feliciani z Instytutu Prawa Kanonicznego św. Piusa X w Wenecji. W swoim wystąpieniu podkreślił, że Jan Paweł II zabiegał, aby gwarancje wolności religijnej - fundamentalnego prawa człowieka - nie pozostawały jedynie deklaracjami, ale były realnie przestrzegane. Prelegent zwrócił uwagę na negatywny stosunek Jana Pawła II do rozwiązań prawnych utożsamiających prawo religijne z prawem państwowym, co prowadzi do dyskryminacji czy prześladowania różnych grup ludności.

Następnie temat Konkordaty Jana Pawła II zaprezentował ks. prof. dr hab. Józef Krukowski (KUL/UKSW) wskazując na bardzo duże zaangażowanie Papieża Polaka w regulowanie sytuacji Kościoła w poszczególnych państwach za pomocą umowy międzynarodowej. Prelegent wskazał na trzy zasady, na których opierają się konkordaty zawierane po Soborze Watykańskim II, tj. poszanowania i ochrony wolności sumienia i religii, autonomii i niezależności państwa i Kościoła oraz współdziałania tych podmiotów dla dobra indywidualnego i wspólnego, a także na specyficzną dla konkordatów Jana Pawła II zasadę poszanowania dziedzictwa duchowego danego narodu. Ks. prof. Krukowski stwierdził, że celem konkordatów jest uzyskanie gwarancji prawnych dla zabezpieczenia wolności należnej Kościołowi jako instytucji życia publicznego, a także określił ich miejsce w systemie źródeł prawa kanonicznego oraz świeckiego. Prelegent zwrócił także uwagę na konieczną dobrą wolę polityczną władz państwowych w procesie negocjacji i ratyfikacji umowy ze Stolicą Apostolską. Jako przykład tego typu trudności ks. prof. Krukowski podał historię ratyfikacji obowiązującego konkordatu z Rzecząpospolitą Polską. Z ostatnim referatem podczas konferencji - Zadania uniwersytetów katolickich wedtug Jana Pawta II - wystąił ks. prof. ndzw. dr hab. Piotr Stanisz podkreślając rolę uniwersytetu katolickiego w poszukiwaniu prawdy oraz w dziele nowej ewangelizacji. Odwołując się do wypowiedzi Papieża Polaka prelegent wskazał na główne wyzwania stojące przed uniwersytetami katolickimi zarówno w zakresie podejmowanych badań naukowych w poszukiwaniu pełnej prawdy, jak i działalności na rzecz wspólnoty Kościoła. Mówca zaakcentował cztery cechy uniwersytetu katolickiego według św. Jana Pawła II. Cechami tymi są: chrześcijańska inspiracja, refleksja podejmowana w świetle wiary, wierność wobec Bożego orędzia oraz instytucjonalne zaangażowanie w służbę ludowi Bożemu i rodzinie ludzkiej. 
Program każdej sesji uzupełniała dyskusja, w której podnoszono kwestie budzące szczególne zainteresowanie lub wątpliwości. Na zakończenie konferencji ks. prof. P. Stanisz dokonał jej podsumowania, wyrażając przekonanie o stałej aktualności nauczania św. Jana Pawła II dla współczesnego Kościoła. Podziękował prelegentom i uczestnikom za wzięcie udziału w obradach. Wyraził także słowa wdzięczności wobec swoich współpracowników z Katedry Prawa Wyznaniowego KUL za zaangażowanie w organizację konferencji.

mgr lic. Konrad Dyda Wydziat Prawa, Prawa Kanonicznego i Administracji Katolicki Uniwersytet Lubelski Jana Pawła II

\section{Międzynarodowa konferencja naukowa pt. Religion, Cooperation, and Conflict in Diverse Societies, Lozanna (Szwajcaria), 4-7 lipca 2017 r.}

W dniach 4-7 lipca 2017 roku w Szwajcarii odbyła się 34. Międzynarodowa Konferencja Naukowa pt. Religion, Cooperation, and Conflict in Diverse Societies zorganizowana przez ISSR (International Society for the Sociology of Religion - Międzynarodowe Towarzystwo Socjologów Religii) we współpracy z Uniwersytetem w Lozannie.

Konferencja rozpoczęła się od uroczystego zebrania członków ISSR w dniu 4 lipca 2017 roku. Obrady konferencji zostały podzielone na pięć sesji plenarnych (głównych) oraz na dziesięć sesji tematycznych. Pierwsza sesja tematyczna, w ramach której zostało równolegle wygłoszonych 50 referatów skupiona była na takich zagadnieniach jak: Religiosity: Analysis of International and national Quantitative Surveys; Conversion and Socio-Political Commitment; Religion and non-Religion Across Generations; Religious and Cultural Syncretism, Interpenetration, Fundamentalism, Intolerance and Conflict in Brazil, France and Elsewhere; Culturel, Indigenous Contemporary Religiosities: Between Solidarity, Contestation, Convergence and Renewal; Media and Religion in East Asia; Governing Religious Diversity and Conflict in the City; Global Pentecostal Charismatic Christianities; Judaism, Judaicities. Mutations and Evolutions of the Contempoprary Jewish World; Migration, Religion and Identity; Current 